Democracy and Moral

Development 



\section{Democracy and Moral Development}

\section{David L. Norton}


University of California

Berkeley and Los Angeles, California

University of California Press

Oxford, England

Copyright $\mathbb{0} 1991$ by The Regents of the University of California

Library of Congress Cataloging-in-Publication Data

Norton, David L.

Democracy and moral development / David L. Norton.

p. $\mathbf{c m}$.

Includes bibliographical references and index.

ISBN 0-520-07067-4 (alk. paper)

1. Political ethics-History. 2. Ethics, Comparative. 3. Ethics, Greek. I. Title.

JA79.N67 1991

$172-\mathrm{dc} 20$

90-37723

CIP

Printed in the United States of America

1223456789

The paper used in this publication meets the minimum requirements of American National Standard for Information Sciences-

Permanence of Paper for Printed Library Materials, ANSI Z39.48-

$1984 @$ 
For Mary 
